\title{
PRIMJENA SFM METODE U PREDMJERU ZEMLJANIH RADOVA
}

\author{
APPLICATION OF SFM METHOD IN THE \\ EARTHWORK BILL OF MEASUREMENTS
}

\author{
Damjan Jurković ${ }^{*}$ Andrej Galović ${ }^{*}$ Iva Grgurić* Emina \\ Imširević ${ }^{*}$ Gorana Galić ${ }^{*}$, Ivan Marović ${ }^{* *}$
}

\begin{abstract}
Sažetak
Razvojem digitalnih tehnologija pojavila se mogućnost njihova korištenja u tradicionalnim granama kao što je građevinarstvo. Pritom, tradicionalne, geodetske metode koje koristimo pri predmjeru zemljanih radova mogu se osnažiti novim digitalnim metodama kao što je SfM („Structure from Motion“). Svrha korištenja navedenih digitalnih tehnologija je $u$ dobivanju bržih $i$ preciznijih rezultata. Predstavljena je procedura izmjere volumena SfM metodom iz 3D modela terena, koja je primijenjena na gradilištu u širem području grada Rijeke. Izrađeni su modeli stvarnog iskopa softverima Meshroom, Autodesk Recap, Meshlab i Blender. Cilj rada je usporedba točnosti rezultata proizašlih iz SfM metode s tradicionalnim, geodetskim, metodama izmjere. Dobiveni rezultat uspoređen je s planiranim volumenom iskopa $i$ stvarnim količinama iz geodetskih snimki iskazanih u građevinskoj knjizi. Također, analizirani su problemi koji su se pojavili tijekom prikupljanja podataka i njihova modeliranja te je dana ocjena primjenjivosti ovih metoda u svakodnevnoj praksi.
\end{abstract}

Ključne riječi: predmjer radova, fotogrametrija, SfM, digitalizacija, volumen iskopa

\begin{abstract}
With the development of digital technologies, the possibility of their use in traditional branches such as construction has emerged. At the same time, the traditional, geodetic methods that we use in the earthwork bill of measurements can be strengthened by

* Sveučilište u Rijeci, Građevinski fakultet, Radmile Matejčić 3, 51000 Rijeka E-mail: \{djurkovic, agalovic2, igrguric, eimsirevic, ggalic\}@student.uniri.hr

** Sveučilište u Rijeci, Građevinski fakultet, Radmile Matejčić 3, 51000 Rijeka E-mail: ivan.marovic@gradri.uniri.hr
\end{abstract}


new digital methods such as SfM ("Structure from Motion"). The purpose of using these digital technologies is to obtain more accurate results faster. The procedure of measuring the volume with the use of SfM method from the $3 D$ terrain model obtained from a construction site in the wider area of the city of Rijeka is presented. Models of real excavation were made with the Meshroom, Autodesk Recap, Meshlab and Blender softwares. The aim of this paper is to compare the accuracy of the results derived from the SfM method with traditional, geodetic measurement methods. The obtained result was compared to the planned excavation volume and the actual quantities from the geodetic surveys presented in the construction book. Also, the problems that arose during data collection and modeling were analyzed and the applicability of these methods in everyday practice was assessed.

Keywords: bill of measurements, photogrammetry, SfM, digitization, excavation volume

\section{Uvod}

Predmet istraživanja ovoga rada je primjena suvremenih digitalnih tehnologija, poput Structure-from-Motion (SfM) metode, pri izmjeri volumena terena za potrebe predmjera zemljanih radova. $\mathrm{Za}$ primjer prikazan u ovom radu prikupljene su fotografije iskopa građevne jame pomoću kojih je uz pomoć fotogrametrije izrađen 3D model iste. Pomoću modela dobiven je volumen građevinske jame koji je uspoređen $\mathrm{s}$ referentnim vrijednostima, odnosno geodetskom izmjerom.

Osnovno načelo fotogrametrije jest da se ista točka može prepoznati na barem dvije fotografije i da se može rekonstruirati u njezinim 3D koordinatama kada su poznati parametri unutarnje orijentacije fotoaparata i vanjski orijentacijski parametri okvira. Pritom softveri koriste posebne algoritme koji su formirani tako da automatski prepoznaju značajke $u$ svakom okviru te ih kao takve uspoređuju s odgovarajućim ekvivalentom na svim fotografijama na kojima se pojavljuju. Koristeći ovaj skup sličnosti kao ulaz, SfM procjenjuje mjesto tih ključnih točaka unutar koordinata lokalnog referentnog sustava kako bi stvorio 3D oblak točaka (eng. point cloud) koji opisuje geometriju promatrane situacije gdje svaka točka ima svoju x, y, z i RBG informaciju. Tri informacije se odnose na koordinatu (koja može i ne mora biti georeferencirana), dok jedna informacija daje boju dotičnoj točki. Sljedeći korak je generiranje 3D gustog oblaka točaka promatranog objekta s mogućim skaliranjem i/ili georeferenciranjem modela te integriranja točaka oblaka, tj. dobivanje tzv. mesh point clouda [1].

Tijekom proteklog desetljeća, potpomognuti radovima navedenim $u$ nastavku temeljenim na geometriji dobivenoj pomoću više fotografija, zanimanje za ovu problematiku značajno se povećalo. To je dovelo do razvoja komercijalnih i softverskih rješenja otvorenog koda, koja se više 
fokusiraju na točnost generiranih 3D modela. Koristeći bespilotne letjelice, autori [2] su s različitih visina $(20,40$ i $75 \mathrm{~m})$ i odabirom novih „ključnih točaka“, odnosno meta, mjerili preciznost dobivenih mjerenja te su svakim novim mjerenjem dobili sve točnije rezultate.

U radu [3], uz pomoć snimaka iz bespilotne letjelice, a koristeći terestričko lasersko snimanje te fotogrametriju, autori su se bavili praćenjem i procjenjivanjem površinskih kopova i okoline, točnije, optimizacijom kuta nagiba površinskog kopa zbog pune upotrebe resursa za recikliranje, smanjenja troškova proizvodnje i povećanja učinkovitosti rudarstva. Dva problema koja se nameću u korištenju navedenog pristupa snimanja za ovakve slučajeve su da se kamenolomi obično nalaze na udaljenim planinskim područjima te cijena tehnike praćenja tla, koja može biti jako visoka. Usporedbu preciznosti mjerenja i udaljenosti promatranog problema opisali su James i Robson [4] u svome radu u kojem uspoređuju okamenjeni vulkanski uzorak i uzorak kratera vulkana Piton de la Fournaise. Također su koristili slobodno dostupne softvere, odnosno kombinaciju SfM i MVS (multiview-stereo) metoda za usporedbu s podacima dobivenim laserskim skeniranjem. Kao rezultat istraživanja, dobivena preciznost je iznosila 1:1000, što znači da je preciznost modela na razini 1 centimetra na udaljenosti mjerenja od 10 metara. Time su pokazali da SfM metoda može dati doista precizne rezultate i na zahtjevnim lomljenim plohama [4]. Pomoću metode 3D geovizualizacije autori [5] su željeli pružiti potporu u praćenju aktivnosti geokonzervacije na zaštićenim geološkim nalazištima, i to na procesima iskopavanja fosilnih nalazišta. Nakon uspješno provedenih mjerenja stvorene su 2D i 3D geovizualizacije koje prikazuju promjene iskopa kroz vrijeme. Drugim riječima, nastale su dvije kartografske ljestvice koje prikazuju prostorno-vremenske promjene iskopa. Jedinstvenim integralnim mjernim sustavom koji se sastoji od GNSS mjerne opreme i ehosondera, autori [6] su mjerili preciznost izmjere kubature iskopa šljunka iz jezera Cirkovljan te zaključili da se pomoću navedenih metoda mogu dobiti precizni rezultati ukoliko je iskop pravilan. $\mathrm{U}$ usporedbi s tradicionalnim metodama izmjere na terenu dobili su gotovo jednake rezultate i na nepravilnom iskopu.

$\mathrm{Na}$ primjeru procjene stabilnosti obalnih litica [7,8], kao izrazito razvedenih i nepravilnih ploha, korištenjem digitalne fotografije autori su testirali kombiniranu metodu koja je uključivala model konzolne zrake i SfM metodu. Uz pomoć SfM-a riješeni su problemi položaja i geometrije scene, ali i višestruka poklapanja i pomaci fotografija. Pokazalo se da je SfM metoda vrlo primjenjiva za proučavanje dinamike šljunkovitih plaža i geomorfologije litica na lokalitetu Stara Baška $[7,8]$ te je zaključeno kako se izrazito složeni oblici u prostoru mogu uspješno snimiti SfM metodom u dijelovima te potom izraditi cjelokupni 3D model ukoliko postoje kontrolne točke za orijentaciju i spajanje. 
Pozitivna strana ovakvog modeliranja prilikom izvođenja zemljanih radova jest jednostavnost prikupljanja podataka. Stoga, veliku pažnju treba posvetiti načinu uzimanja fotografija i georeferenciranju uzetih fotografija. Jednostavnost se ogleda u tome što softver, ukoliko nema nikakvih smetnji, vrlo brzo i jednostavno izradi model promatranog objekta. Negativna strana modeliranja prilikom izvođenja zemljanih radova jest smetnja teksture materijala promatranog objekta. Dakle, ukoliko je površina promatranog objekta kontinuirana i glatka, softveri 3D model objekta izrade jednostavno i brzo $[9,10]$. Međutim, ukoliko se radi o materijalu koji posjeduje određene neravnine na površini, kao u slučaju našeg promatranog modela, modeliranje postaje kompleksnije i potencijalno ima veća odstupanja [11-13]. U tom slučaju je bitno da osoba koja izrađuje model posjeduje određena znanja i vještine kako bi se problemi prilikom modeliranja uspješno otklonili. Neke od konvencionalnih metoda izmjere nisu pogodne za korištenje ili ih je pak nemoguće koristiti na nepristupačnim objektima i objektima [8] vrlo velikih dimenzija, što je primjenom novih tehnologija moguće.

Uzimajući u obzir sve navedeno, potrebno je biti pažljiv prilikom odabira kutova snimanja i, nakon toga, odabira snimljenih fotografije na temelju kojih se stvara 3D model. Brojni autori $[4,7,8,14]$ napominju kako je potrebno uvijek imati i snimak koji je napravljen nekom drugom metodom ili posjedovati precizne kontrolne točke, tzv. ground control points (GCP).

Cilj rada je usporedba točnosti rezultata proizašlih iz SfM metode $s$ tradicionalnim, geodetskim metodama izmjere. Pritom je predstavljena procedura izmjere volumena SfM metodom iz 3D modela terena. Dobiveni rezultati su uspoređeni s planiranim volumenom iskopa i stvarnim količinama iz geodetskih snimki, iskazanih u građevinskoj knjizi. Također, tijekom izrade rada analizirani su problemi koji su se pojavili tijekom prikupljanja podataka i njihovog modeliranja te je dana ocjena primjenjivosti ovih metoda. Jedan od razmatranih problema je broj fotografija i to utjecaj broja fotografija na točnost rezultata, zatim kutovi fotografiranja i tekstura promatranog objekta.

\section{Pristup primjeni SfM metode pri izradi modela 3D terena}

Proces izmjere volumena SfM metodom iz 3D modela terena (Slika 1) u metodološkom smislu sastoji se od dvije glavne faze:

- 1. faza - prikupljanje podataka na terenu i

- 2. faza - obrada podataka u uredu. 


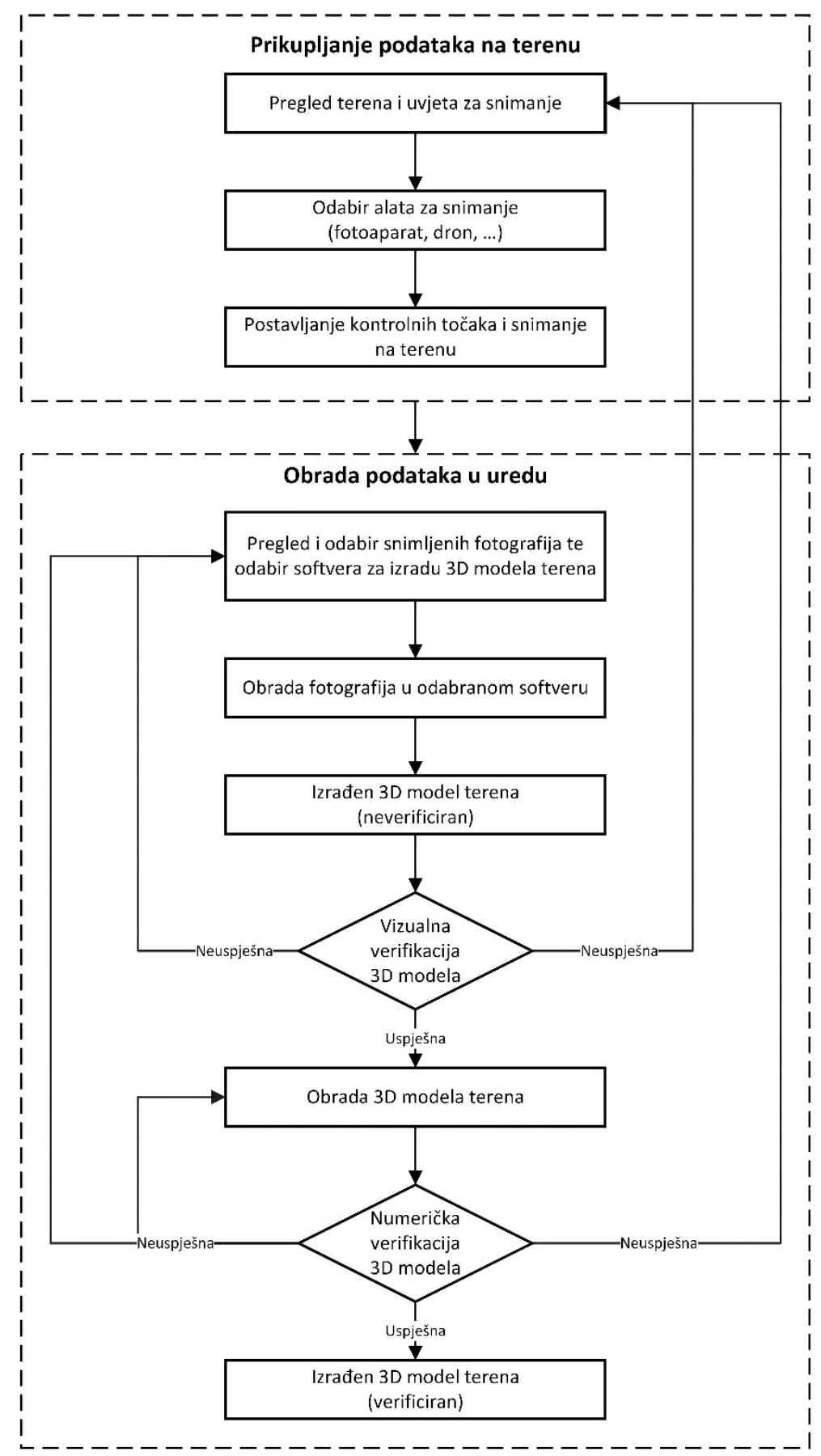

Slika 1. Metodološki prikaz procesa izmjere volumena SfM metodom iz 3D modela terena 
Prikupljanje podataka na terenu podijeljeno je na tri koraka. Prvi korak je pregled terena i uvjeta za snimanje. U njemu prikupljamo sve potrebne informacije pomoću kojih kasnije odlučujemo o vrsti alata za snimanje i softvera koje ćemo koristiti pri izradi 3D modela terena. U ovom se koraku promišlja o geometriji, veličini i poziciji promatranog prostora kojeg moramo snimiti te vremenskim uvjetima tijekom provođenja samog snimanja. Na temelju utvrđenih svojstava problema (mjesto i vremenski uvjeti), u drugom koraku odabire se alat za snimanje, koji može biti fotoaparat, pametni telefon, bespilotna letjelica (dron) ili neka udruga tehnologija (npr. laser, lidar, satelit, i sl.). U trećem koraku postavljamo kontrolne točke na području snimanja (unutar i izvan objekta koji se snima). Kontrolne točke su potrebne prilikom kasnije obrade fotografija te prilikom provođenja fotogrametrije. Na kraju prve faze snimamo proizvoljan broj fotografija s ciljem dobivanja "realnog" tj. "realističnog” 3D modela terena. Pritom je potrebno voditi računa o pozicijama snimanja i smjeru snimanja tj. kutovima snimanja u odnosu na objekt.

S prikupljenim fotografijama terena ulazimo u drugu fazu, fazu obrade podataka u uredu, koja se sastoji od više koraka. Tijekom same faze, u dva navrata provodimo ocjenu kvalitete rezultata, pri kojima procjenjujemo zadovoljavaju li rezultati vizualne, odnosno numeričke kriterije. U slučaju da ne zadovoljavaju, potrebno je vratiti se na neki od prijašnjih koraka faze „Obrada podataka u uredu“ ili pak faze „Prikupljanje podataka na terenu“.

Prvi korak druge faze sastoji se od pregleda i odabira snimljenih fotografija te odabira softvera za izradu 3D modela terena. Potrebno je racionalizirati broj fotografija koje će se koristiti kako bi skratili vrijeme generiranja modela i smanjili potrebnu snagu računala, a da u isto vrijeme kvaliteta modela ostane na zadovoljavajućoj razini. Prema potrebi, softver odabiremo ovisno o vrsti problema, prijašnjem osobnom iskustvu i financijskim mogućnostima. Fotografije unosimo u odabrani softver te kroz proces fotogrametrije kao povratnu informaciju dobivamo 3D model terena u obliku mreže elemenata koja čini njegovu plohu. Vizualno procjenjujemo je li model u skladu sa stvarnim volumenom, odnosno odgovara li geometrija situaciji na terenu. Ako geometrija nije zadovoljavajuća, npr. nedostaju dijelovi mreže i/ili postoje geometrijski oblici kojih nema u stvarnosti, vraćamo se na korak odabira fotografija i softvera i ponavljamo postupak. Ako nakon ponovljenog postupka model ponovno ne zadovoljava vizualnu procjenu, potreban je povratak na teren. Ako model zadovoljava vizualnu procjenu, prelazi se na sljedeći korak, a to je obrada 3D modela. U ovom koraku vršimo popravak manjih geometrijskih nedostatka te pomoću kontrolnih točaka model skaliramo na njegovu stvarnu veličinu. Obrađenom modelu softverski mjerimo volumen, a zatim vršimo numeričku verifikaciju modela. Postavljaju se dvije granice odstupanja. 
Pogreška unutar prve granice koja je postavljena kao 5\% odstupanja predstavlja zadovoljavajuću pogrešku pa tu vrijednost možemo prihvatiti kao približno točnu veličinu volumena. Druga granica određena je vrijednošću od $10 \%$ odstupanja te su odstupanja veća od toga apsolutno neprihvatljiva. Za pogrešku između prve i druge granice potreban je povratak na korak odabira fotografija i softvera za obradu i, po potrebi, povratak na teren ako to smatramo potrebnim. Ako je pogreška veća od druge granice, povratak na teren je neizbježan jer treba prikupiti nove podatke. Izrađeni 3D model terena na kraju 2. faze predstavlja verificirani model koji odgovara stvarnom stanju na terenu.

\section{Rezultati i diskusija}

Navedeni metodološki pristup primijenjen je na gradilištu skladišta JGL-a na Kukuljanovu (Slika 2) za izmjeru volumena iskopa temelja samca. Fotografiranje je izvršeno u popodnevnim satima sunčanog dana te je na taj način eliminiran utjecaj sjena na teksture modela (Slika 3).

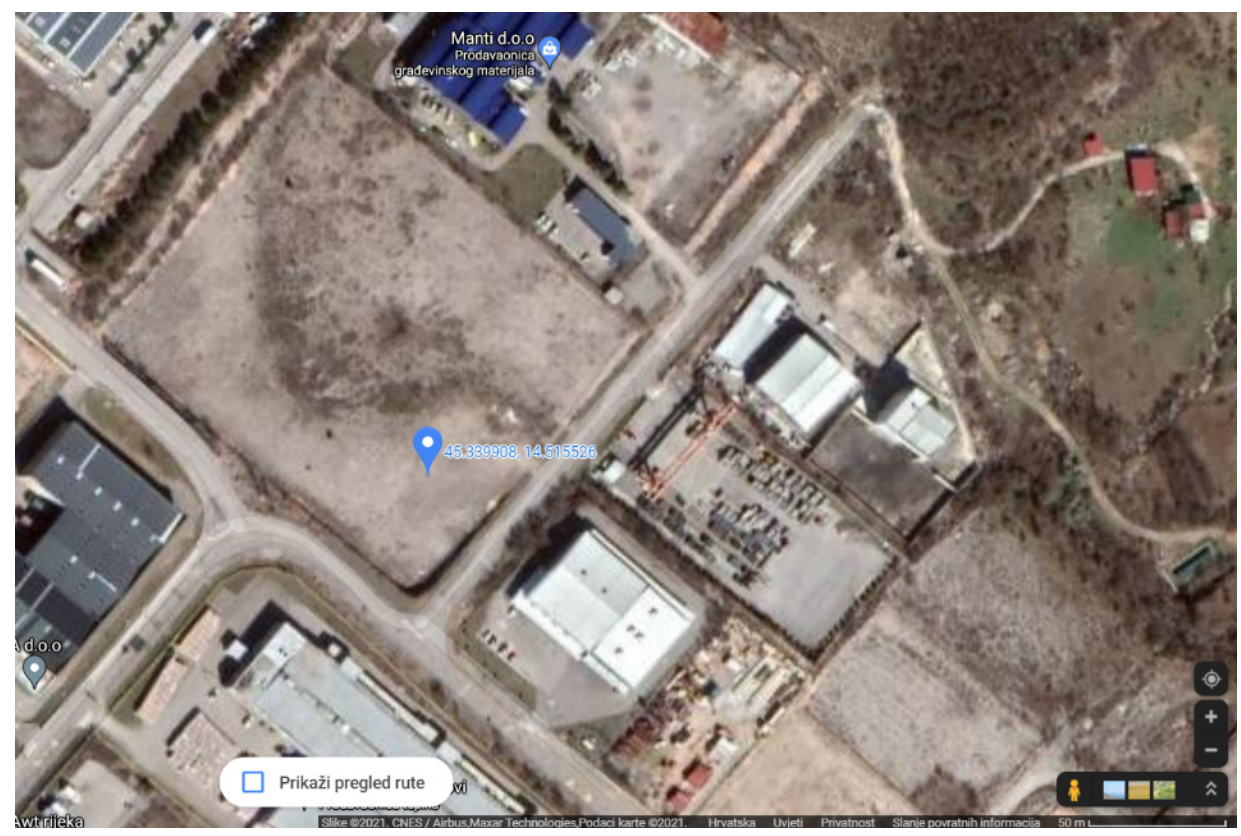

Slika 2. Karta lokacije mjerenja [izradili autori] 


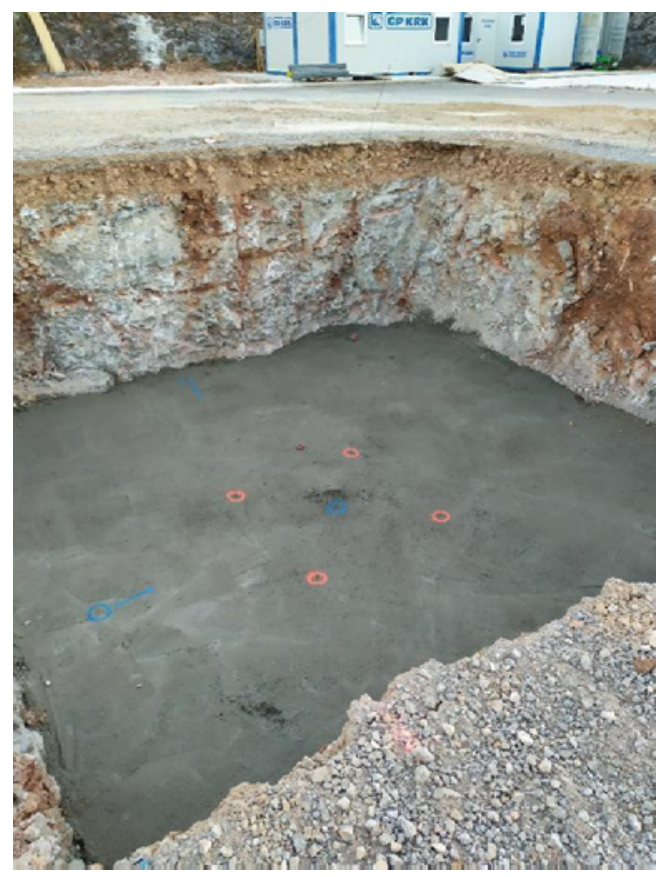

Slika 3. Prikaz iskopa/primjer fotografije korištene za izradu modela [izradili autori]

Sveukupno je izrađeno 58 fotografija uz pomoć pametnog telefona Xiaomi Redmi Note 7. Korištena je stražnja kamera od 12 MP sa sekundarnom kamerom od 5 MP koja služi kao dubinski senzor, dok žarišna duljina kamera iznosi $5 \mathrm{~mm}$. Sve snimljene fotografije su dimenzija 3000x4000 piksela. Vrijeme ekspozicije snimljenih fotografija se kretalo u rasponu od 1/100 do $1 / 166$ s, brzina senzora svjetlosti ISO 100 i otvor blende f/1,8. Fotografije su izrađene s 10 različitih točaka obzirom na oblik iskopa, dok su položaji tih točaka odabrani na način da se obuhvate sve stranice iskopa iz različitih kutova (Slika 4).

Za fotogrametrijsku metodu korištena su dva komercijalna softvera, Meshroom (www.alicevision.org) i Autodesk Recap (www.autodesk.com/ products/recap). Radi ispitivanja utjecaja broja fotografija na točnost napravljeno je sedam modela, od čega su četiri korištena u nastavku rada. U svakom softveru generiran je model sa svih 58 fotografija te je kasnije taj broj smanjivan na način da broj fotografija u svakoj točci snimanja bude jednak. Na taj način su dobiveni modeli koji su nazvani 58, 40, 30 i 20, ovisno o broju fotografija od kojih su modelirani. Model od 20 fotografija nije bilo moguće generirati u softveru Autodesk Recap zbog ograničenosti minimalnog broja fotografija koji iznosi 20 , dok su ostali modeli obrađeni u softverima Meshlab (www.meshlab.net) i Blender (www.blender.org). 


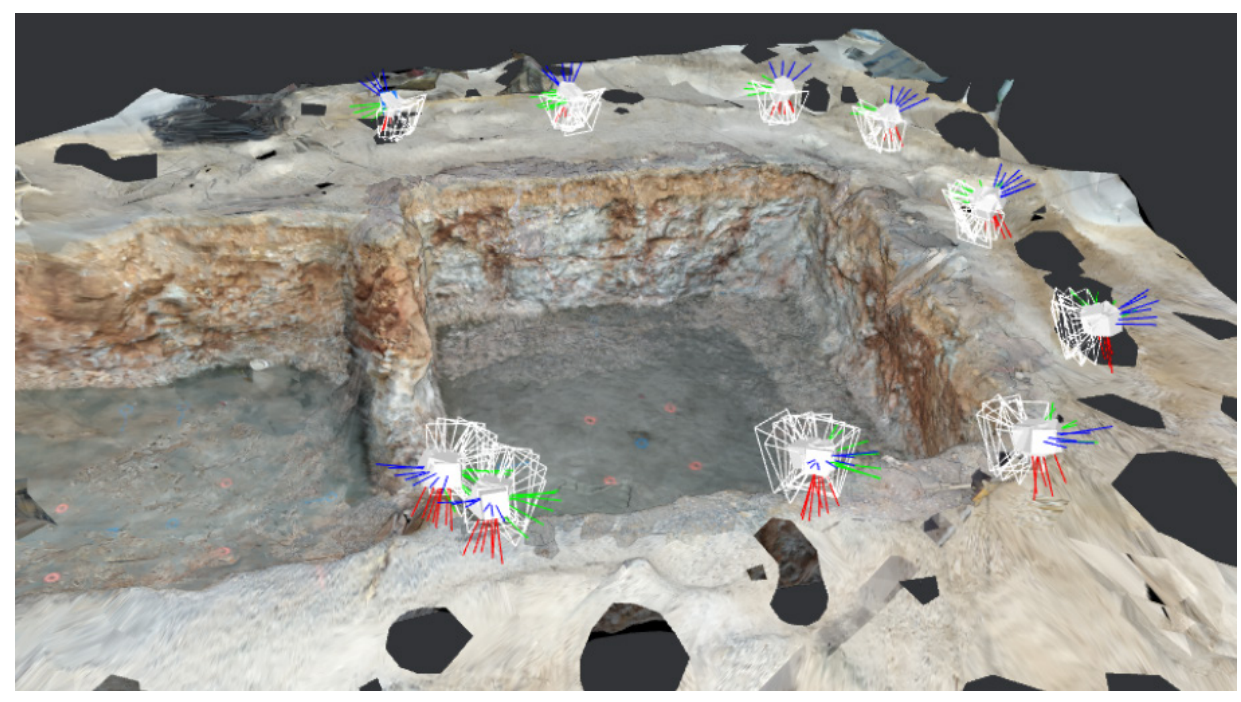

Slika 4. Položaj točaka snimanja [izradili autori]

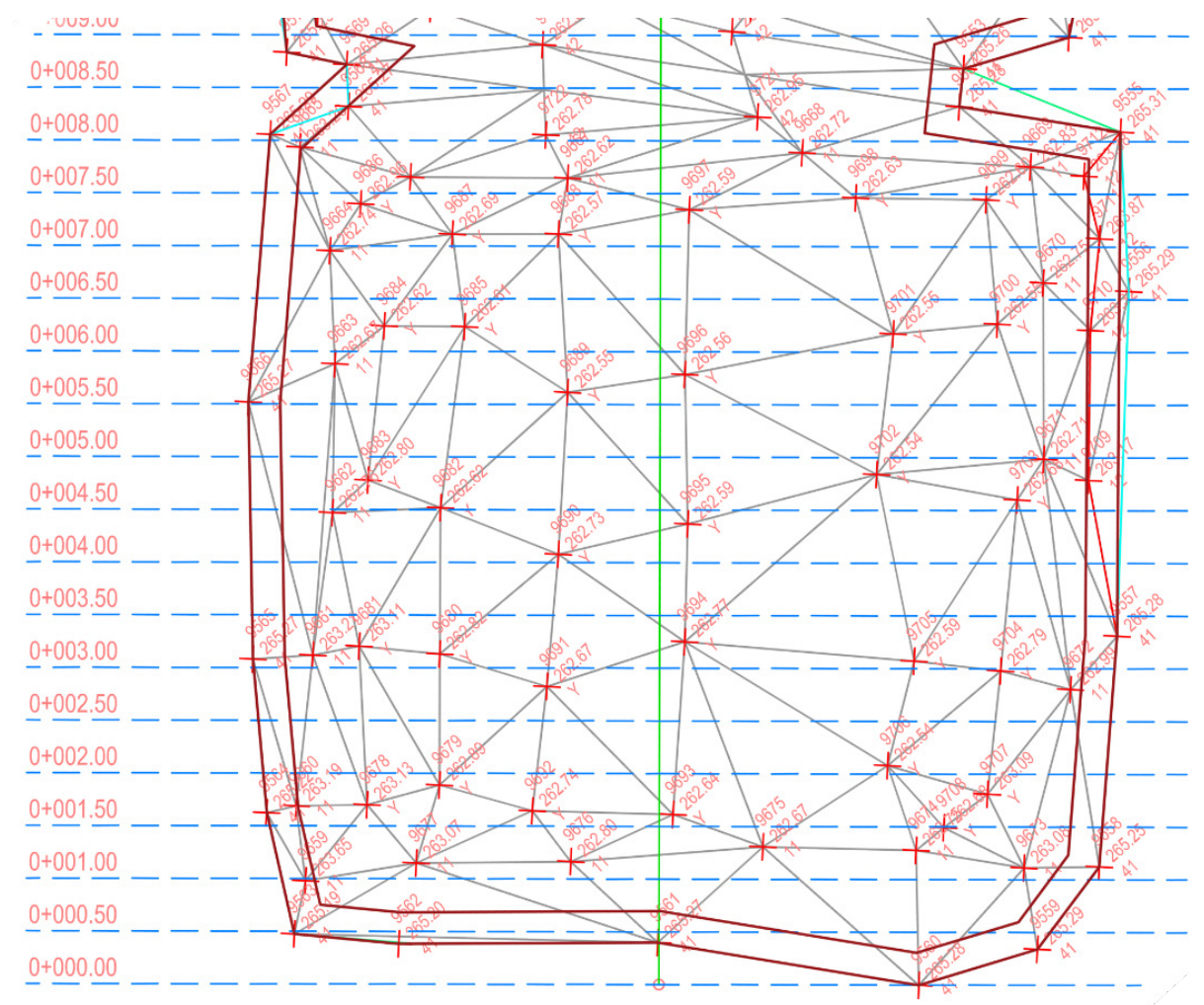

Slika 5. Detalj iskopa iz geodetskog elaborata (stacionaža od 0,00 do +8,50 m) 
Volumeni stvorenih 3D modela su izmjereni u softveru Blender, dok su kao kontrolne vrijednosti korišteni podaci o volumenu iskopa po stacionažama iz građevinske knjige, dobiveni geodetskom izmjerom. Na Slici 5 prikazan je detalj iskopa (stacionaža od 0,00 do $+8,50 \mathrm{~m}$ ) iz geodetskog elaborata.

U Tablici 1 dana je usporedba dobivenih volumena četiri modela (broj fotografija 58, 40, 30 i 20) s izvedenim stanjem za stacionaže $0,00-7,50 \mathrm{~m}$, $0,00-8,00 \mathrm{~m}$ i $0,00-8,50 \mathrm{~m}$. Također, izraženo je odstupanje od izvedenog stanja $\mathrm{u} \mathrm{m}^{3}$ te u postotnom omjeru.

$\mathrm{U}$ Tablici 2 na isti su način prikazani rezultati za modele izrađene $u$ softveru Autodesk Recap. Prosječno odstupanje izraženo u postotnom omjeru iznosi 17,8\% za modele izrađene u softveru Meshroom te $18,7 \%$ za one izrađene u softveru Autodesk Recap.

Za prvu granicu zadovoljavajućeg odstupanja odabrana je vrijednost od $5 \%$ vrijednosti iz građevinske knjige. Navedena granica je odabrana kao konzervativno tumačenje prihvatljive pogreške sukladno uvaženoj građevinskoj praksi u izvedbi zemljanih radova koja iznosi $+/-2,5 \mathrm{~cm}$ na 1 $\mathrm{m}^{1}$, dok je kao druga granica određena vrijednost od $10 \%$ koja se temeljem prijašnjih istraživanja smatra opravdanom. Pretvorbom navedene pogreške u volumen dobivamo prihvatljivu pogrešku od 15,6\% koja je veća od pretpostavljenih.

Tablica 1. Usporedba volumena dobivenih softverom Meshroom s izvedenim stanjem

\begin{tabular}{|c|c|c|c|c|}
\hline Model & $\begin{array}{c}\text { Stacionaža } \\
(\mathrm{m})\end{array}$ & $\begin{array}{c}\text { Volumen } \\
\left(\mathrm{m}^{3}\right)\end{array}$ & $\begin{array}{c}\text { Odstupanje } \\
\left(\mathrm{m}^{3}\right)\end{array}$ & $\begin{array}{c}\text { Postotak } \\
(\%)\end{array}$ \\
\hline \multirow{3}{*}{$\begin{array}{l}\text { Izvedeno } \\
\text { stanje }\end{array}$} & 7,50 & 126,0 & 0 & 0 \\
\hline & 8,00 & 134,3 & 0 & 0 \\
\hline & 8,50 & 140,1 & 0 & 0 \\
\hline \multirow{3}{*}{58} & 7,50 & 152,8 & 26,8 & 17,6 \\
\hline & 8,00 & 162,5 & 28,3 & 17,4 \\
\hline & 8,50 & 167,9 & 27,8 & 16,6 \\
\hline \multirow{3}{*}{40} & 7,50 & 149,4 & 23,4 & 15,7 \\
\hline & 8,00 & 160,2 & 25,9 & 16,2 \\
\hline & 8,50 & 166,6 & 26,5 & 15,9 \\
\hline \multirow{3}{*}{30} & 7,50 & 160,4 & 34,4 & 21,5 \\
\hline & 8,00 & 171,8 & 37,6 & 21,9 \\
\hline & 8,50 & 180,4 & 40,3 & 22,4 \\
\hline \multirow{3}{*}{20} & 7,50 & 149,7 & 23,7 & 15,8 \\
\hline & 8,00 & 160,1 & 25,9 & 16,2 \\
\hline & 8,50 & 167,5 & 27,4 & 16,4 \\
\hline \multicolumn{4}{|c|}{ Prosjek } & 17,8 \\
\hline
\end{tabular}


Tablica 2. Usporedba volumena dobivenih softverom Autodesk Recap $s$ izvedenim stanjem

\begin{tabular}{|c|c|c|c|c|}
\hline Model & $\begin{array}{c}\text { Stacionaža } \\
(\mathrm{m})\end{array}$ & $\begin{array}{c}\text { Volumen } \\
\left(\mathrm{m}^{3}\right)\end{array}$ & $\begin{array}{c}\text { Odstupanje } \\
\left(\mathrm{m}^{3}\right)\end{array}$ & $\begin{array}{c}\text { Postotak } \\
(\%)\end{array}$ \\
\hline \multirow{3}{*}{$\begin{array}{l}\text { Izvedeno } \\
\text { stanje }\end{array}$} & 7,50 & 125,9 & 0 & 0 \\
\hline & 8,00 & 134,3 & 0 & 0 \\
\hline & 8,50 & 140,1 & 0 & 0 \\
\hline \multirow{3}{*}{58} & 7,50 & 153,6 & 27,7 & 18,0 \\
\hline & 8,00 & 163,7 & 29,5 & 18,0 \\
\hline & 8,50 & 168,7 & 28,7 & 17,0 \\
\hline \multirow{3}{*}{40} & 7,50 & 155,8 & 29,8 & 19,1 \\
\hline & 8,00 & 166,0 & 31,7 & 19,1 \\
\hline & 8,50 & 171,1 & 31,1 & 18,1 \\
\hline \multirow{3}{*}{30} & 7,50 & 157,0 & 31,0 & 19,8 \\
\hline & 8,00 & 167,5 & 33,2 & 19,8 \\
\hline & 8,50 & 172,6 & 32,6 & 18,9 \\
\hline \multicolumn{4}{|c|}{ Prosjek } & 18,7 \\
\hline
\end{tabular}

Dobivena pogreška je veća od druge pretpostavljene granice od 10\%. Nakon nekoliko povrataka na odabir fotografija i njihove obrade zaključeno je kako je potreban povratak na teren radi izrade novih fotografija, no radi tempa izvedbe objekta nije bilo moguće ponoviti snimanje.

Prijašnji radovi navedeni u uvodu daju teoretsku osnovu na temelju koje se može zaključiti da je točnije rješenje, odnosno volumen bliži onome dobivenom geodetskom izmjerom moguć. Stoga pogrešku koja se pojavila $\mathrm{u}$ rezultatima prvenstveno pripisujemo nedostatku kontrolnih točaka, tzv. GCP. Naime, kao referentne točke iskorištene su oznake za ugradnju armaturnih koševa na mršavom betonu. Time smo dobili referentne točke u ravnini paralelnoj ravnini dna iskopa. Kako nismo imali visinsku referencu, pretpostavljamo da se upravo tu pojavilo izobličenje modela koje je rezultiralo razlikom u odnosu na stvarno izvedeno stanje.

Uzimajući u obzir prethodno spomenutu prihvatljivu pogrešku u izvedbi zemljanih radova sukladno uvaženoj građevinskoj praksi $(15,6 \%)$, opravdano se upitati o pogrešci SfM metode od 17,8\% tj. 18,7\%. Kako klasična geodetska izmjera daje podatke u točkama između kojih se teren interpolira, nije isključeno da primjena SfM metode možda daje i bolje podatke jer pritom uzima u obzir utjecaj svih neravnina koji se mogu pojaviti u zasjecima iskopa.

Na Slici 6 prikazan je omjer broja fotografija korištenih za izradu modela i odstupanje volumena modela od izvedenog stanja u presjecima 
na stacionažama $+7,50,+8,00$ i $+8,50 \mathrm{~m}$. Vidljivo je kako smanjenjem broja fotografija za izradu modela u softveru Autodesk Recap odstupanje od izvedenog stanja raste, što je i očekivano. No trend nije takav kod softvera Meshroom, gdje na prvi pogled odstupanje od izvedenog stanja nije obrnuto proporcionalno broju korištenih fotografija. Moguć uzrok tome je odabir fotografija koje su unesene u modele; naime, odstupanje je gotovo jednako za oba softvera kada su unesene sve snimljene fotografije, ali kod smanjenja broja fotografija odstupanje u rezultatima je značajnije te mijenja predznak ovisno o broju fotografija. Važno je naglasiti kako softver Meshroom generira model koristeći računalo na kojemu se nalazi, dok softver Autodesk Recap koristi vanjski hardver povezan na Autodeskov cloud. Odstupanja od točnosti mogu biti rezultat pojednostavljenja generiranja unutar softvera Meshroom radi optimizacije softvera dostupnoj računalnoj snazi.

Smanjivanje broja fotografija za izradu modela ovakvog tipa iskopa ne utječe na točnost. No, kod modela 30 može se uočiti da pristup odabira fotografija ipak može utjecati na točnost. Kao što je ranije navedeno, naš pristup smanjenja broja fotografija je bio taj da broj fotografija u svakoj točci snimanja bude jednak. U slučaju dotičnog modela očito se gubi određeni broj informacija potrebnih za stvaranje 3D modela te da je odabir fotografija (zbog kutova snimanja te preklapanja snimljenoga na fotografijama) važan korak u fazi obrade podataka u uredu.

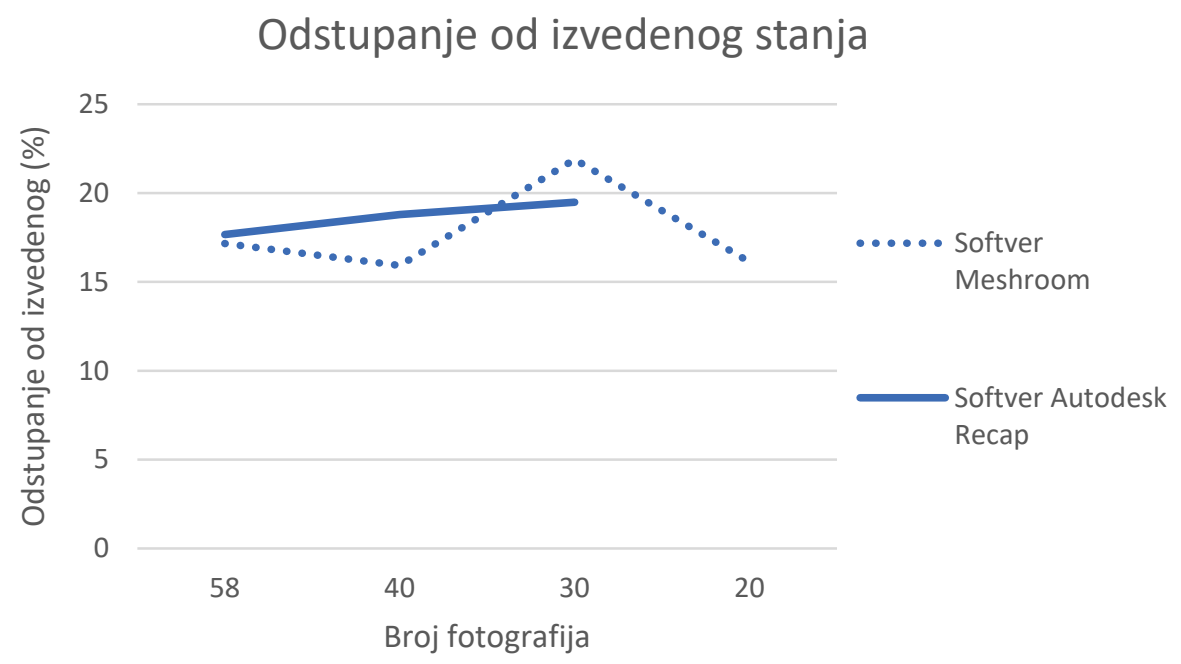

Slika 6. Usporedba odstupanja modela od izvedenog stanja ovisno o broju fotografija 


\section{Zaključak}

U ovom radu prikazan je pristup primjene SfM metode pri izradi 3D modela terena na primjeru iskopa temelja samca. Uz razvoj pristupa, glavni cilj rada bio je usporediti izračun količina iz 3D modela terena s tradicionalnim geodetskim metodama izmjere. Model građevinske jame izrađen je uz pomoć dva softvera, pri čemu je došlo do razlike u iskazu količina između izvedenog stanja i 3D modela proizašlog iz Meshroom $(17,8 \%)$ i Autodesk Recap $(18,7 \%)$ softvera. Najveći utjecaj na ustanovljenu pogrešku bila je posljedica nekorištenja kontrolnih točaka po obodu građevinske jame i okolnog terena. Zbog nemogućnosti povratka na teren nije bilo moguće ponoviti postupak s većim brojem fotografija. Iako su na ovom primjeru građevne jame ustanovljena odstupanja između količina iz geodetskog elaborata i izrađenog 3D modela terena, uspostavljena procedura je obećavajuća. U nastavku istraživanja planirano ju je dodatno ispitati primjenu na drugim tipovima iskopa odnosno drugim gradilištima.

Zahvala. Ovaj članak je proizašao iz seminarskog rada u sklopu kolegija Upravljanje projektima na diplomskog studiju. Autori se zahvaljuju uredniku $i$ recenzentima na korisnim savjetima i preporukama te voditeljima gradilišta iz tvrtke GP Krk d.d. koji su omogućili provođenje terenskih mjerenja i ustupili podatke potrebne za usporedbu. Objava ovog rada je podržana od strane Sveučilišta u Rijeci u okviru projekta „Koncept za podršku odlučivanju pri održivom upravljanju urbanih sredina" (uniri-pr-tehnic-19-18).

\section{Literatura}

[1] Medić, T. (2015). Izmjera nepristupačnih područja pomoću bespilotnih letjelica. Diplomski rad, Zagreb: Geodetski fakultet.

[2] Urbančič, T., Roškar, Ž., Kosmatin Fras, M., Grigillo, D. (2019). New Target for Accurate Terrestrial Laser Scanning and Unmanned Aerial Vehicle Point Cloud Registration. Sensors, 19(14), 3179.

[3] Tong, X., Liu, X., Chen, P., Liu, S., Luan, K., Li, L., Liu, S., Liu, X., Xie, H., Jin, Y., Hong, Z. (2015). Integration of UAV-based Photogrammetry and Terrestrial Laser Scanning for the Three-Dimensional Mapping and Monitoring of OpenPit Mine Areas. Remote Sensing, 7(6), 6635-6662.

[4] James, M.R., Robson, S. (2012). Straightforward Reconstruction of 3D Surfaces and Topography with a Camera: Accuracy and Geoscience Application. Journal of Geophysical Research: Earth Surface, 117(F3), doi:10.1029/2011JF002289

[5] Papadopoulou, E. E., Kasapakis, V., Vasilakos, C., Papakonstantinou, A., Zouros, N., Chroni, A., Soulakellis, N. (2020). Geovisualization of the Excavation Process in the Lesvos Petrified Forest, Greece Using Augmented Reality. ISPRS International Journal of Geo-Information, 9(6), 374. 
[6] Grgić, I., Drvenkar, D., Šantek, D. (2017). Računanje volumena iskopa na jezeru Cirkovljan. Geodetski list, 71(1), 77-94.

[7] Ružić, I., Marović, I., Benac, Č., Ilić, S. (2014). Coastal Cliff Geometry Derived from Structure-from-Motion Photogrammetry at Stara Baška, Krk Island, Croatia. Geo-Marine Letters, 34(6), 555-565.

[8] Ružić, I., Benac, Č., Marović, I., Ilić, S. (2015). A stability Assessment of Coastal Cliffs Using Digital Imagery. Acta Geotechnica Slovenica, 2, 25-35.

[9] Gordon, S.J., Lichti, DD (2007). Modeling Terrestrial Laser Scanner Data for Precise Structural Deformation Measurement. Journal of Surveying Engineering, 133(2), doi:10.1061/(ASCE)0733-9453(2007)133:2(72)

[10] Fook, H. (2008). 3D Terrestrial Laser Scanning for Application in Earthwork and Topographical Surveys. Bachelor thesis. University of Southern Queensland, Faculty of Engineering and Surveying, Australia.

[11] Opitz, R. S., Johnson, T. D. (2016). Interpretation at the Controller's Edge: Designing Graphical User Interfaces for the Digital Publication of the Excavations at Gabii (Italy). Open Archaeology, 2(1).

[12] Bitelli, G., Girelli, V. A., Sammarini, G. (2018). 4-Dimensional Recording and Visualization of Urban Archeological Excavations. Applied Geomatics, 10(4), 415-426.

[13] Erenoglu, O. (2021). UAV for 3D Morphological Mapping Applications: A Case Study of Koru Mining Site, Canakkale, NW Turkey. Tehnički vjesnik, 28(3), 1044-1050.

[14] Westoby, M.J., Brasington, J., Glasser, N.F., Hambrey, M.J., Reynolds, J.M. (2012). Structure-from-Motion Photogrammetry: a Low-Cost, Effective Tool for Geoscience Applications. Geomorphology, 179, 300-314. 